\title{
PERAN PEREMPUAN DALAM PELAKSANAAN SYARIAT ISLAM DI PROVINSI ACEH
}

\author{
Muhsinah \\ Universitas Islam Negeri Ar-Raniry, Banda Aceh \\ Jl. Syeikh Abdul Arauf Kopelma Darussalam Banda Aceh, 23112 \\ e-mail:muhsinah1963@gmail.com \\ Sulaiman \\ STAI-PTIQ Banda Aceh \\ Jl. Nasional Banda Aceh-Meulaboh. Km 157. Krueng Sabe. Kabupetan Aceh Jaya-Provinsi Aceh, 23654 \\ e-mail: sulaiman.man684@gmail.com
}

\begin{abstract}
Abstrak: Penelitian ini membahas bagaimana persepsi masyarakat terhadap kedudukan perempuan dalam posisi strategis di lingkungkan Dinas Syariat Islam Provinsi Aceh, dan kendala optimalisasi peran perempuan dalam penerapan syariat Islam di Aceh. Penelitian ini menggunakan metode kualitatif. Analisis data menggunakan pendekatan deskriptif. Hasil penelitian menunjukkan bahwa perempuan Aceh terlibat aktif dalam pelaksanaan syariat Islam di Aceh, terdapat perbedaan persepsi masyarakat terkait peran perempuan pada jabatan strategis pada Dinas Syariat Islam. Optimalisasi peran perempuan dalam pelaksanaan syariat Islam dilakukan melalui pelibatan pada struktur pemerintah dan non-pemerintah dan pelatihan pengembangan kompetensi. Secara keseluruhan tidak terdapat kendala terhadap optimalisasi peran perempuan terhadap pelaksanaan syariat Islam di Provinsi Aceh.
\end{abstract}

\begin{abstract}
Woman's Role in Islamic Shariah in Aceh Province. This study discusses how people's perceptions of woman's role in strategic positions within Aceh Province, and the constraints of optimizing their participation in the application of Islamic law in Aceh. This study uses a qualitative method with descriptive data analysis approach. The results showed that Acehnese women were actively involved in the implementation of Islamic law in Aceh, there were differences in community perceptions regarding the role of women in strategic positions in the Office of Islamic Law. Optimizing efforts of their role is done through involving them in government and non-government structures and competencies improvement. Overall there are no obstacles to optimizing the role of women in the implementation of Islamic law in Aceh Province.
\end{abstract}

Kata Kunci: perempuan, Aceh, syariat Islam, gender 


\section{Pendahuluan}

Aceh adalah daerah keistimewaan berdasarkan Undang-Undang (UU) Nomor 44 tahun 1999 dan satu-satunya provinsi yang mendapatkan otonomi khusus terkait pelaksanaan syariat Islam, tepatnya sejak dideklarasikan syariat Islam pada tanggal 1 Muharam $1423 \mathrm{H}$ bertepatan dengan tanggal 15 Maret 2002. Keistimewaan Aceh ditetapkan dalam Undang-Undang Nomor 44 Tahun 1999 tentang penyelenggaraan keistimewaan bagi Daerah Istimewa Aceh. Adapun cakupan keistimewaan yang ditetapkan dalam undang-undang tersebut mencakup 4 (empat) bidang, yaitu bidang syariat Islam, bidang adat istiadat, bidang pendidikan dan peran ulama dalam struktur pemerintahan. Kemudian, pelaksanaan syariat Islam di Aceh ini diperkuat kembali dengan UU Nomor 18 Tahun 2001 dan UU Nomor 11 Tahun 2006 tentang Pemerintahan Aceh.

Penerapan syariat Islam di Aceh kini sudah 16 tahun sejak pertama kali disahkan pada tahun 2002. Rentang waktu tersebut tergolong lama dan seharusnya sekarang pelaksanaan syariat Islam di Aceh dapat terlaksana secara efektif. Disebutkan demikian karena penerapan syariat Islam di Aceh sampai saat ini masih terjadi kekurangan dan pelanggaran sehingga muncul spekulasi penilaian dari masyarakat yang beragam. Penilaian masyarakat terhadap syariat Islam di Aceh secara umum ada yang pro syariat Islam dan ada yang kontra. Kalangan pro syariat menilai bahwa penerapan syariat Islam di provinsi Aceh sekarang meningkat lebih maju (progres) dan berproses secara efektif. Namun berbeda dengan kalangan yang kontra, mereka menilai penerapan syariat Islam di Propinsi Aceh suatu kemunduran dan tidak menghargai hak-hak manusia dengan memberikan hukuman cambuk. Penerapan syariat Islam di provinsi Aceh tentu harus melibatkan seluruh masyarakat baik kaum laki-laki dan perempuan, keduanya memiliki fungsi strategi terhadap penerapan syariat Islam. Kaum perempuan khususnya sangat berperan terhadap keberhasilan pelaksanaan syariat Islam di Aceh dalam berbagai sisi. Perempuan jadi figur syariat bagi anak-anak di rumah dan di biokrasi pemerintahan di Aceh.

Keterlibatan perempuan dalam berbagi sektor di Aceh sudah teruji secara historis. ${ }^{1}$ Munawiyah merujuk pada penjelasan A. Hasjmy bahwa di Aceh sejak dari kerajaan Islam Perlak, Kerajaan Samudara/Pase sampai kepada Kerajaan Aceh Darussalam, masyarakatnya dibina berdasarkan ajaran Islam, maka secara teoretis menempatkan kedudukan lakilaki dan perempuan pada posisi sebagaimana diatur oleh Islam. Ajaran Islam yang bersumber dari al-Qur'an, Sunnah, ijmak dan kias, tidak menempatkan laki-laki dan perempuan pada posisi yang diskriminatif. Hal ini sebagaimana peran pada masa kerajaan Aceh yang diatur dalam Adat Meukuta Alam Kerajaan Aceh Darussalam. ${ }^{2}$ Posisi perempuan dalam kerajaan Aceh Darussalam tidak terdiskriminasi dan mendapat perlakuan sebagaimana ketetapan al-Qur'an dan Sunnah.

\footnotetext{
${ }^{1}$ Sulaiman, Studi Syariat Islam di Aceh (Banda Aceh: Madani Publisher, 2018), h. 37.

${ }^{2}$ Munawiyah, "Kedudukan Perempuan dalam Budaya Aceh," dalam Jurnal Ar-Raniry Media Kajian Keislaman, Vol. 1, No. 87, 2011, h. 124.
} 
Bukti lain keterlibatan perempuan Aceh dalam berbagai sektor juga sebagaimana penjelasan Munawiyah bahwa perempuan Aceh pantas berbangga, sebab Aceh banyak sekali tokoh perempuan yang terlibat di ranah publik. Dalam bidang politik dan pemerintahan tampil Putri Lindung Bulan, Ratu Nur Ilah, Ratu Nahrasiah, Safiatuddin Syah, Naqiatuddin Syah, Inayat Syah, Kamalat Syah, Putrou Phang dan Pocut Baren. ${ }^{3}$ Selain itu terdapat pula tokoh perempuan Aceh yang terlibat dalam bidang militer dan agama seperti Laksamana Malahayati, Cut Nyak Dhien, Cut mutia dan Teungku Fakinah. Bahkan pada pemerintahan Sultanah Safiatuddin Syah, Majelis Mahkamah Rakyat Aceh Besar beranggotakan perempuan sebanyak 15 orang dalam jumlah keseluruhan 75 orang. ${ }^{4} \mathrm{Jadi}$, kedudukan perempuan di Aceh sangat sentral dalam berbagai peran baik dalam bidang politik, militer, agama dan sosial.

Keterkaitan dengan pelaksanaan syariat Islam di provinsi Aceh sebagaimana pada saat sekarang, perempuan memiliki peran penting terhadap sosialisasi syariat Islam dalam keluarga, masyarakat, dan bahkan terlibat di biokrasi pemerintahan. Pelibatan perempuan bertujuan untuk menyukseskan pelaksanaan syariat Islam dan perannya sama dengan kaum laki-laki. Hal ini sebagaimana penjelasan Abu Bakar bahwa mengenai izin atau aturan tentang keterlibatan perempuan di dalam bidang kegiatan publik dan politik adalah sama. Lebih lanjut Abu Bakar menjelaskan bahwa pada masa Rasulullah, perempuan terlibat di dalam berbagai kegiatan publik dan politik, sebagai pedagang, berkebun, mengerjakan berbagai industri, termasuk ikut ke dalam medan perang bukan hanya sebagai perawat tetapi juga memegang senjata ketika keadaan memerlukannya. ${ }^{5}$ Penjelasan tersebut mengindikasikan, perempuan dalam konteks pelaksanaan syariat Islam di Aceh memiliki peran yang sama dengan laki-laki. Artinya perempuan dapat mengambil posisi strategis dalam pelaksanaan syariat Islam di Aceh. Posisi strategis tersebut bisa dalam fungsi sosialisasi di keluarga, masyarakat dan Kepala Dinas Syariat Islam di Aceh. Idealnya demikian, peran perempuan diberikan peluang dan peran sebagaimana kaum pria di Aceh.

Peran perempuan tidak bisa ditinggalkan dalam konteks penerapan syariat Islam di Aceh dalam kapasitas apa pun; masyarakat biasa, tokoh ulama perempuan di Aceh dan aktivis pemerhati syariat Islam. Kesamaan perlakuan dan peran perempuan dalam mendukung keberhasilan pelaksanaan syariat Islam di Aceh juga sebagaimana penjelasan Kepala Dinas Syariat Islam, Dr. Munawar, MA pada pembukaan acara pembekalan syariat Islam bagi tokoh, bahwa sebagian isu yang berkembang pada periode ini menyangkut peran perempuan ke ranah publik, dan isu tersebut berkembang sehingga menjadi perbincangan yang hangat. Banyak isu beredar saat ini terkadang menyudutkan dan

${ }^{3}$ Ibid.

${ }^{4}$ Ibid.

${ }^{5}$ Al Yasa Abubakar, Bunga Rampai Pelaksanaan Syariat Islam: Pendukung Qanun Pelaksanaan Syariat Islam (Banda Aceh: Dinas Syariat Islam, 2009), h. 196. 
menghina Islam dengan isu-isu negatif, seolah-olah Islam tidak memberikan ruang gerak dan kesempatan bagi perempuan. Padahal isu tersebut, hanya dibuat oleh orang atau oknum yang tidak bertanggung jawab dengan bertujuan mendiskreditkan Islam. Padahal Islam tidak membenarkan menyakiti orang lain, termasuk menyakiti kaum perempuan. ${ }^{6}$ Tidak ada pembatasan keterlibatan perempuan dalam meraih kesuksesan penerapan syariat Islam di Aceh.

Penelitian tentang perempuan dan penerapan syariat Islam di Aceh pada dasarnya sudah banyak dilakukan oleh penulis sebelumnya. Di antaranya adalah Muhammad (2008), Huda (2013), Nasir (2013), Raihan (2015), Saiful (2016), Keumala, et al (2017), Mahfud, et al. (2017), Mahmudin (2019) dan Hidayati (2019). Tetapi, penelitian ini lebih spesifik meneliti peran perempuan dalam pelaksanaan syariat Islam.

Perempuan Aceh pada dasarnya telah berkontribusi besar dan terlibat secara aktif terhadap penerapan syariat Islam di Aceh, misalnya dalam keluarga perempuan selain berperan sebagai istri dan ibu bagi anak-anak, juga berperan sebagai pembimbing dan pelaku sosialisasi penerapan syariat Islam bagi keluarga, anak-anak, dan juga bagi masyarakat umum. ${ }^{7}$ Selain peran tersebut, perempuan Aceh juga diberi kesempatan yang sama dalam birokrasi pemerintahan, khususnya pelibatan perempuan pada Dinas Syariat Islam provinsi dan kabupaten/kota. Namun demikian, meskipun perempuan diberi peran yang sama dengan kaum pria dalam penerapan syariat Islam di Aceh, tetapi pada realitasnya masih terjadi pendikotomian di biokrasi Dinas Syariat Islam Aceh. Disebutkan demikian, karena saat ini 17 tahun sudah penerapan syariat Islam di Aceh, namun belum pernah perempuan menjadi Kepala Dinas Syariat Islam, padahal banyak sekali perempuan Aceh yang sangat potensial.

Demikian permasalahan di lapangan terkait pengoptimalan peran perempuan, khususnya dalam penerapan syariat Islam di provinsi Aceh. Untuk itu, menurut peneliti, ini merupakan permasalahan yang menarik dikaji lebih mendalam terkait dengan pelibatan perempuan di birokrasi Dinas Syariat Islam di Aceh dan peran perempuan Aceh secara umum terhadap penerapan syariat Islam di Provinsi Aceh.

\section{Metode Penelitian}

Penelitian ini dilakukan dengan menggunakan metode penelitian kualitatif. ${ }^{8}$ Teknik

6 “Tokoh Perempuan dan Da'iyah Aceh Menjadi Garda Terdepan Dalam Pelaksanaan Syariat Islam di Aceh," in https://dsi.acehprov.go.id/tokoh-perempuan-dan-daiyah-menjadigarda-terdepan-dalam-pelaksanaan-syariat-islam-di-aceh/, 30 Agustus 2017.

${ }^{7}$ Al Yasa Abu Bakar, Bunga Rampai Pelaksanaan, h. 212.

${ }^{8}$ Sugiyono, Metode Penelitian Pendidikan Pendekatan Kuantitatif, Kualitatif, dan R \& (Bandung: Alfabeta, 2011), h. 15. 
pengambilan subyek penelitian secara purposive, ${ }^{9}$ karena atas dasar pertimbangan ${ }^{10}$ subyek tersebut dapat memberikan informasi yang akurat terhadap penelitian yang sedang dilakukan. Adapun subjek penelitian ini tepatnya berada di tiga lokasi kabupaten/kota provinsi Aceh, yaitu Pidie Jaya, Aceh Selatan, dan Aceh Utara yang ditentukan secara purposive, terdiri dari 3 orang Kepala Dinas Syariat Islam atau pejabat terkait, dan karyawan perempuan serta 15 orang masyarakat. Teknik pengumpulan data menggunakan wawancara, dokumentasi, dan observasi. Sedangkan analisis menggunakan pendekatan deskriptif.

\section{Hasil dan Pembahasan}

Pelaksanaan syariat Islam di Provinsi Aceh secara keseluruhan telah melibatkan perempuan dalam berbagai kesempatan di Aceh. Sistem pelaksanaan syariat Islam dilaksanakan dalam konteks demokrasi dan tidak ada dikotomi terhadap perempuan Aceh bahkan pemerintah Aceh melibatkan perempuan dalam rangka pembangunan Provinsi Aceh dalam konteks pelaksanaan syariat Islam.

Perempuan Aceh juga ikut berperan aktif dalam sistem pelaksanaan syariat Islam pada kantor Dinas Syariat Islam di tingkat provinsi dan kabupaten/kota. Perempuan dan laki-laki sama-sama dirangkul oleh pemerintah untuk pengoptimalisasian pelaksanaan syariat Islam di Aceh.

Masyarakat Aceh menyambut baik dan memiliki persepsi positif terhadap peran serta perempuan dalam posisi strategis pada kantor Dinas Syariat Islam. Keterlibatan perempuan dalam posisi strategis pada kantor Dinas Syariat Islam, berupa sekretaris kantor, Kepala Bagian, dan Polisi Syariat (wilayatul hisbah) di Provinsi Aceh. Namun demikian, masih terdapat pula sebagian pendapat masyarakat yang kurang mendukung terhadap pelibatan perempuan ke publik dengan alasan tidak relevan dengan budaya Aceh dan adat istiadat Aceh.

\section{Peran Perempuan Aceh dalam Penerapan Syariat Islam}

Perempuan Aceh pada hakikatnya sama saja dengan perempuan negara lain dan kota-kota di Indonesia. Halimah dan Hasibuan menjelaskan menurut empat ormas Islam di Indonesia, perempuan dan laki-laki memiliki relasi yang sama. ${ }^{11}$ Namun demikian, perempuan Aceh memiliki sisi yang sangat berbeda dengan perempuan-perempuan pada

${ }^{9}$ Noeng Muhadjir, Metodologi Penelitian Kualitatif (Yogyakarta: Bayu Indra Grafika, 1996), h. 28.

${ }^{10}$ Suharsimi Arikunto, Manajemen Penelitian (Jakarta: Rineka Cipta, 2003), h. 128.

${ }^{11}$ Siti Halimah \& Humaidah Hasibuan, "Respons Tokoh Ormas Islam Terhadap Peran Publik Perempuan," dalam MIQOT: Jurnal Ilmu-ilmu Keislaman, Vol. 42, No. 2, 2018, h. 406423; Mhd. Syahnan et al., "Reconsidering Gender Roles in Modern Islam: A Comparison of the Images of Muslim Women Found in the Works of Sayyid Qutb and 'Â'ishah 'Abd Rahmân," dalam International Journal of Humanities and Social Science Invention Vol. 6 (10) 2017, h. 37-42. 
umumnya. Perbedaan tersebut dilihat dari aspek historis, perempuan Aceh ikut terlibat aktif dalam berbagai aktivitas di Aceh, panglima perang melawan penjajahan Belanda, politik, ${ }^{12}$ pemerintahan, ekonomi, pendidikan, sosial, ${ }^{13}$ dan bahkan terlibat aktif dalam pelaksanaan syariat Islam di Aceh.

Aceh adalah satu-satunya provinsi di Indonesia yang memberlakukan syariat Islam. Penerapan syariat Islam di Provinsi Aceh berlandaskan pada UU Nomor 44 Tahun 1999 tentang keistimewaan Propinsi Nanggroe Aceh Darussalam dalam bidang agama, pendidikan, budaya dan peradatan, dan peran ulama. Setelah Undang-Undang tersebut, pemerintah pusat kembali mengeluarkan kebijakannya dengan Undang-Undang Nomor 18 Tahun 2001 tentang Otonomi Khusus untuk Propinsi Nanggroe Aceh Darussalam. Melalui kebijakan ini, pemerintah daerah Propinsi Aceh memiliki kewenangan yang luas dalam pengelolaan sistem pemerintahan Aceh termasuk pelaksanaan syariat Islam di Aceh.

Pelaksanaan syariat Islam di provinsi Aceh kini sudah berjalan 19 tahun dan mengalami perkembangan yang cukup signifikan. Disebutkan demikian, karena pemahaman masyarakat terkait pelaksanaan syariat Islam di Aceh mengalami kemajuan dan peningkatan, meskipun masih terdapat pelanggaran-pelanggaran.

Kesuksesan pelaksanaan syariat Islam di Provinsi Aceh tidak terlepas dari peran kaum perempuan Aceh. Perempuan-perempuan Aceh telah ambil bagian berpartisipasi secara aktif dalam mendukung pemerintah terhadap pelaksanaan syariat Islam di Aceh. Perempuan telah ambil bagian dan berperan aktif dalam berbagai sektor di Propinsi Aceh dalam konteks pelaksanaan syariat Islam di Aceh.

Keterlibatan perempuan dalam multi aspek dalam sistem pemerintahan Aceh dalam konteks penerapan syariat Islam diperkuat dengan berbagai informasi penelitian. Hal ini sebagaimana penjelasan salah satu Kepala Dinas Syariat Islam di kabupaten/kota di Aceh, bahwa perempuan ikut ambil peran aktif dalam sistem pemerintahan Aceh dalam konteks pelaksanaan syariat Islam di Propinsi Aceh maupun di kabupaten/kota. ${ }^{14}$ Penjelasan hampir sama dijelaskan oleh Kepala Dinas Syariat Islam Kabupaten Pidie Jaya bahwa peran perempuan sangat membantu pemerintah dalam percepatan pembangunan di Aceh dalam bingkai pelaksanaan syariat Islam di Aceh, perempuan telah ambil peran dalam berbagai sistem pemerintahan dan banyak perempuan Aceh yang memiliki kompetensi sangat baik dan perlu didukung oleh pemerintah dalam pemanfaatan dan pengoptimalisasian perempuan dalam sistem pemerintah Aceh. ${ }^{15}$

${ }^{12}$ Abidin Nurdin, et al., Syariat Islam dan Isu-Isu Kontemporer (Banda Aceh: Dinas Syariat Islam, 2011), h. 116; Mhd. Syahnan, Hukum Islam dalam Bingkai Transdisipliner (Medan: Perdana Publishing), 2018.

${ }^{13}$ Nurul Fajriah, et al., Dinamika Peran Perempuan Aceh Dalam Lintasan Sejarah (Banda Aceh: Yayasan PeNa, 2007), h. 99.

${ }^{14}$ Wawancara dengan Kepala Dinas Syariat Islam Aceh Selatan, 6 Juni 2018.

${ }^{15}$ Wawancara dengan Kepala Dinas Syariat Islam Pidie Jaya, 24 Juni 2018. 
Perempuan Aceh juga terlibat dalam multi bidang dan ini merupakan suatu keunikan yang dimiliki perempuan Aceh. Keterlibatan mereka dalam multi bidang sebagaimana penjelasan kepala Dinas Syariat Islam Kabupaten Aceh Selatan bahwa perempuan Aceh unik, disebutkan unik karena perempuan Aceh sangat tangguh, mereka dapat berpartisipasi dan berperan aktif dalam berbagai bidang, khususnya terkait dengan pelaksanaan syariat Islam di Aceh. Perempuan Aceh berperan aktif bersama laki-laki dalam menjaga dan melaksanakan syariat Islam, dan sekaligus ada yang terlibat secara langsung sebagai pegawai pada kantor Dinas Syariat Islam. ${ }^{16}$

Peran perempuan Aceh dalam multi/berbagai bidang juga dibenarkan oleh kepala Dinas Syariat Islam Kabupaten Aceh Utara bahwa perempuan Aceh memiliki motivasi yang cukup bagus dalam multi bidang. Mereka memiliki kemampuan yang luar biasa dalam berbagai bidang profesi seperti bekerja sebagai petani, pegawai pemerintah, pengusaha, dan pendidik baik pada sekolah, madrasah, dan lembaga pendidikan dayah di Aceh. ${ }^{17}$ Berbagai aspek tersebut tidak terlepas dari pelaksanaan syariat Islam di Aceh dan telah melibatkan perempuan.

Perempuan Aceh juga terlibat aktif dalam sistem politik. Perempuan juga menjadi pelaku demokrasi. ${ }^{18}$ Pelaksanaan syariat Islam di Aceh tidak membatasi terhadap perempuan di Provinsi Aceh untuk ikut terlibat dalam bidang politik atau bergabung dalam partai politik di Aceh. Hal ini sebagaimana ketetapan Undang-Undang Nomor 11 Tahun 2016 Tentang Pemerintahan Aceh bahwa 30\% dari anggota partai politik harus diisi oleh perempuan. Keterkaitan antara perempuan Aceh dan partai politik pada sistem pemerintahan Aceh dalam konteks pelaksanaan syariat Islam tidak dipermasalahkan dan bahkan perempuan wajib terlibat dalam sistem partai.

Salah seorang Kepala Dinas syariat Islam kabupaten/kota menjelaskan bahwa sistem pemerintahan Aceh dalam konteks pelaksanaan syariat Islam di Aceh sangat demokratis. Pelaksanaan syariat Islam tidak membatasi terhadap peran perempuan Aceh dalam bidang politik, mereka memiliki kesempatan yang sama dapat ikut terlibat dalam sistem politik di Aceh. ${ }^{19}$ Penjelasan hampir sama juga diberikan oleh Kepala Dinas Syariat Islam Kabupaten Aceh Utara bahwa semua warga Aceh memiliki hak yang sama dalam bidang politik, tidak ada upaya menghambat terhadap masyarakat yang ingin terjun ke dunia politik, termasuk perempuan diberi kesempatan berpolitik. Pelaksanaan syariat Islam di Aceh tidak mengkungkung hak perempuan Aceh agar tidak berpolitik, bahkan UUPA menetapkan $30 \%$ dari anggota partai harus perempuan. ${ }^{20}$

${ }^{16}$ Wawancara Dengan Kepala Dinas Syariat Islam Aceh Selatan, 6 Juni 2018.

${ }^{17}$ Wawancara Dengan Kepala Dinas Syariat Islam Aceh Utara, 22 Juni 2018.

${ }^{18}$ Saparudin, "Gerakan Keagamaan dan Peta Afiliasi Ideologis Pendidikan Islam di Lombok," dalam MIQOT: Jurnal Ilmu-ilmu Keislaman, Vol. 42, No, 1, 2018, h. 220-241.

${ }^{19}$ Wawancara Dengan Kepala Dinas Syariat Islam Pidie Jaya, 24 Juni 2018.

${ }^{20}$ Wawancara Dengan Kepala Dinas Syariat Islam Aceh Utara, 22 Juni 2018. 
Kepala Dinas Syariat Islam selanjutnya menjelaskan sistem politik di Aceh demokratis dan pelaksanaan syariat Islam di provinsi Aceh tidak membatasi peran perempuan di bidang politik. Faktanya di DPRA dan DPRK, ada perwakilan perempuan dan bahkan perwakilan perempuan di ranah legislatif dapat disebutkan sebagai perwakilan suara dari perempuan dalam hal pembangunan Aceh dalam konteks pelaksanaan syariat Islam di Aceh. ${ }^{21}$ Informasi tersebut mengindikasikan pelaksanaan syariat Islam di Aceh sangat demokratis dan memberikan kesempatan secara luas kepada perempuan maju melalui ranah politik untuk memperkuat sistem pemerintahan Aceh dalam konteks pelaksanaan syariat Islam.

Peran perempuan dalam bidang ekonomi sangat membantu untuk membangun kesejahteraan. ${ }^{22}$ Salah satu aspek penting dalam pelaksanaan syariat Islam di Aceh adalah mewujudkan kesejahteraan dan kemakmuran bagi rakyat. Pelaksanaan syariat Islam di Aceh pada dasarnya tidak hanya untuk memberi sanksi kepada pelanggar syariat Islam, namun aspek kesejahteraan, kemakmuran, dan perekonomian masyarakat merupakan unsur penting dalam konteks pelaksanaan syariat Islam di Aceh.

Salah seorang kepala Dinas Syariat Islam kabupaten dan kota menjelaskan, aspek perekonomian atau pengembangan perekonomian masyarakat agar dapat hidup lebih sejahtera merupakan program yang terintegrasi dalam pelaksanaan syariat Islam di Aceh. Adapun salah satu program pemerintah daerah berupa pengembangan perekonomian masyarakat termasuk melibatkan perempuan dalam bidang pengembangan ekonomi masyarakat, kegiatan ini harus menjadi prioritas. ${ }^{23}$

Peran perempuan dalam bidang ekonomi dalam konteks pelaksanaan syariat Islam di Aceh dapat dilihat dari peran perempuan dalam berbagai kegiatan usaha, misalnya perempuan Aceh ada yang menjadi pengusaha dan sebagai pengelola home industri dan berbagai industri lain. ${ }^{24}$ Kepala Dinas Syariat Islam berikutnya memberikan informasi, kiprah perempuan Aceh dalam bidang perekonomian besar sekali. Saat ini, terdapat para perempuan Aceh yang sudah mandiri dalam bidang perekonomian. Mereka mengelola usaha sendiri sehingga membuka lapangan kerja bagi masyarakat sekitar. Sebagian perempuan Aceh telah sukses membangun berbagai unit usaha, tentunya sangat membantu pemerintah dalam menumbuhkan perekonomian masyarakat yang lebih baik. ${ }^{25}$ Dengan demikian, pemerintah daerah kabupaten dan kota diharapkan dapat membantu unit usaha perempuan Aceh agar pertumbuhan perekonomian masyarakat membaik.

${ }^{21}$ Wawancara Dengan Kepala Dinas Syariat Islam Aceh Selatan, 6 Juni 2018.

${ }^{22}$ Syamsuri \& Okta Yuripta Syafitri, "Maqâshid Syarî'ah Approach on the Empowerment of Human Resources in Mulyodadi Village Bantul Yogyakarta," dalam MIQOT: Jurnal Ilmuilmu Keislaman, Vol. 42. No. 2, 2019, h. 379-405.

${ }^{23}$ Wawancara Dengan Kepala Dinas Syariat Islam Aceh Selatan, 6 Juni 2018.

${ }^{24}$ Wawancara Dengan Kepala Dinas Syariat Islam Pidie Jaya, 24 Juni 2018.

${ }^{25}$ Wawancara Dengan Kepala Dinas Syariat Islam Aceh Utara, 22 Juni 2018. 
Kegiatan sosial perempuan Aceh berfungsi membangun hubungan interaksi antar sesama masyarakat agar semakin erat. ${ }^{26}$ Pelaksanaan syariat Islam di Aceh membuka peluang dan kesempatan untuk semua lapisan masyarakat dalam berperan dan berpartisipasi, termasuk peran perempuan Aceh dapat ikut berpartisipasi di bidang sosial. Keterkaitan dengan hal ini, perlu disikapi bahwa syariat Islam di Aceh tidaklah mengekang perempuan untuk tidak beraktivitas di luar rumah atau dalam bentuk kegiatan sosial. Namun sebaliknya perempuan didorong untuk lebih aktif dalam bidang sosial dengan berpegang teguh pada syariat Islam.

Peran perempuan Aceh di bidang sosial pada dasarnya bukan hanya saat ini dalam konteks pelaksanaan syariat Islam di Aceh, namun perempuan Aceh sudah aktif berperan dalam bidang sosial jauh sebelum pelaksanaan syariat Islam di Aceh sampai dengan saat ini perempuan Aceh terus berkiprah dalam berbagai kegiatan sosial di Aceh.

Peran perempuan Aceh di aspek sosial dalam konteks pelaksanaan syariat Islam di Aceh sebagaimana penjelasan salah satu kepala Dinas Syariat Islam pada tingkat kabupaten dan kota di Aceh, kiprah perempuan di bidang sosial dalam konteks pelaksanaan syariat Islam di Aceh dapat dilihat dari keterlibatan perempuan Aceh dalam berbagai kegiatan sosial dan terlibat pada berbagai organisasi sosial. ${ }^{27}$

Penjelasan tersebut dibenarkan oleh kepala Dinas Syariat Islam di Kabupaten lain, perempuan Aceh saat ini terlibat di berbagi organisasi masyarakat. Hal ini menjadi indikator pelaksanaan syariat Islam di Aceh tidak membatasi terhadap peran perempuan untuk terlibat dalam kegiatan sosial, bahkan perempuan harus diberdayakan untuk mendukung pembangunan dalam konteks pelaksanaan syariat Islam di Aceh. ${ }^{28}$ Penjelasan hampir senada juga di sampaikan oleh kepala Dinas Syariat Islam di kabupaten selanjutnya bahwa perempuan Aceh sangat kreatif dan memiliki kompetensi dan skil sosial, saat ini banyak perempuan Aceh aktif dalam berbagai organisasi sosial. ${ }^{29}$

Berbagai informasi tersebut menunjukkan, perempuan Aceh terlibat dalam berbagai kegiatan sosial di Aceh melalui berbagai organisasi masyarakat, baik di tingkat provinsi, kabupaten kota, dan sampai di tingkat desa. Perempuan Aceh ada membangun kelompok sosial, misalnya melalui kelompok wirid (kelompok zikir perempuan di desa). Kegiatan ini menjadi salah satu aspek kegiatan sosial yang sangat digemari oleh perempuan di Aceh. Hampir di setiap desa terdapat kelompok zikir perempuan.

Perempuan Aceh juga aktif dalam bidang pendidikan yang berperan sebagai pendidik/ guru pada pengajian dan sekolah. Kiprah perempuan sebagai pendidik di Aceh sangat

${ }^{26}$ Muhammad Habibi Siregar, "Islam, Patron Sosial, Pseudo Identitas Masyarakat Perkotaan di Kota Medan," dalam MIQOT: Jurnal Ilmu-ilmu Keislaman, Vol. 41. No.2, 2018, h. 302-334.

${ }^{27}$ Wawancara Dengan Kepala Dinas Syariat Islam Aceh Selatan, 6 Juni 2018.

${ }^{28}$ Wawancara Dengan Kepala Dinas Syariat Islam Aceh Utara, 22 Juni 2018.

${ }^{29}$ Wawancara Dengan Kepala Dinas Syariat Islam Pidie Jaya, 24 Juni 2018. 
membantu pemerintah dalam mempercepat pembangunan Aceh dalam konteks pendidikan islami dan pelaksanaan syariat Islam.

Salah seorang Kepala Dinas Syariat Islam menjelaskan peran perempuan sebagai pendidik selama ini merupakan bentuk partisipasi perempuan untuk membantu pemerintah dalam mentransfer ilmu dan wawasan tentang syariat Islam di Aceh ke pada peserta didik. ${ }^{30}$ Salah seorang Kepala Dinas Syariat Islam menjelaskan peran perempuan sebagai pendidik selama ini merupakan bentuk partisipasi perempuan untuk membantu pemerintah dalam mentransfer ilmu dan wawasan tentang syariat Islam di Aceh kepada peserta didik. Penjelasan hampir sama diberikan oleh kepala Dinas Syariat selanjutnya bahwa peran perempuan penting dalam pelaksanaan syariat Islam. khususnya dalam bidang pendidikan, perempuan Aceh telah mengambil peran sebagai pendidik di sekolah, di madrasah, dan lembaga pendidikan dayah atau pesantren. ${ }^{31}$

Penjelasan hampir serupa dijelaskan oleh kepala Dinas Syariat Islam berikutnya bahwa perempuan Aceh sangat antusias dalam membantu pemerintah terhadap pelaksanaan syariat Islam di Aceh, terutama sekali dalam bidang pendidikan, perempuan Aceh telah membantu pemerintah dalam mensosialisasikan syariat Islam sejak dini kepada anakanak sebagai generasi Aceh melalui pendidikan. ${ }^{32}$ Penjelasan tersebut pada umum hampir serupa dengan penjelasan yang diperoleh dari masyarakat bahwa perempuan Aceh ikut berpartisipasi dalam pelaksanaan syariat Islam di Aceh, mereka telah mengambil peran dalam sektor pendidikan, baik pendidikan yang dikelola oleh pemerintah dan masyarakat. ${ }^{33}$ Penjelasan hampir sama dijelaskan oleh salah seorang masyarakat berikutnya, perempuan Aceh sangat konsisten dalam membantu pemerintah dan sekaligus menjadi sebagai pendidik syariat Islam bagi generasi Aceh, bahkan selama ini banyak perempuan Aceh yang menjadi guru di balai pengajian di desa dan mereka tidak mendapat honor dari pemerintah, namun mereka tetap melaksanakan pengajian bagi anak-anak di Aceh. ${ }^{34}$ Penjelasan serupa juga dijelaskan oleh masyarakat lain bahwa perempuan Aceh sejak dari dulu sangat aktif dalam berbagai kegiatan agama termasuk dalam bidang pendidikan agama di Aceh, mereka telah menjadi guru pengajian pada balai-balai pengajian di Aceh sampai saat ini, mereka mengajar agama kepada anakanak Aceh secara gratis. Namun demikian, perempuan Aceh sangat tekun mengajar agama dan memberi wawasan pelaksanaan syariat Islam di Aceh. ${ }^{35}$

Kiprah perempuan Aceh dalam pelaksanaan syariat Islam di Aceh saat ini sangat tinggi, khususnya pada ranah pendidikan di Aceh. Perempuan Aceh telah mengambil peran

\footnotetext{
${ }^{30}$ Wawancara Dengan Kepala Dinas Syariat Islam Aceh Selatan, 6 Juni 2018.

${ }^{31}$ Wawancara Dengan Kepala Dinas Syariat Islam Pidie Jaya, 24 Juni 2018.

${ }^{32}$ Wawancara Dengan Kepala Dinas Syariat Islam Aceh Utara, 22 Juni 2018.

${ }^{33}$ Wawancara Dengan Masyarakat Aceh Utara, 22 Juni 2018.

${ }^{34}$ Wawancara Dengan Masyarakat Pidie Jaya, 24 Juni 2018.

${ }^{35}$ Wawancara Dengan Masyarakat Aceh Selatan, 6 Juni 2018.
} 
sebagai pendidik, baik pada sekolah, madrasah, balai pengajian di tingkat gampong, dan dayah perempuan yang terdapat di berbagai kabupaten di Provinsi Aceh.

Aktivitas sosialisasi pelaksanaan syariat Islam di Aceh melibatkan berbagai unsur masyarakat termasuk perempuan Aceh sampai di tingkat desa, banyak perempuan Aceh menjadi pembimbing dasar agama pendidikan Islam dan memperkenalkan syariat Islam kepada peserta didik Aceh sebagai generasi bangsa melalui pengajian yang terdapat di rumah warga dan balai-balai pengajian yang dikelola secara mandiri oleh rakyat.

Berdasarkan berbagai informasi tersebut dapat disimpulkan bahwa perempuan Aceh ikut ambil peran dalam pelaksanaan syariat Islam di Aceh melalui aspek pendidikan. Perempuan Aceh aktif terlibat dalam membentuk generasi Aceh yang syar'i melalui pendidikan formal dan non formal yang dikelola secara mandiri oleh masyarakat. Demikian kiprah perempuan dalam pelaksanaan syariat Islam di Aceh.

Perempuan dalam konteks pelaksanaan syariat Islam di provinsi Aceh telah ikut peran aktif dalam berbagai sektor sosial di Aceh. Pelaksanaan syariat Islam di provinsi Aceh tidak membatasi terhadap peran perempuan dalam mengabdi kepada masyarakat di Aceh. Selain itu, perempuan Aceh mendapatkan kesempatan dan hak yang sama dengan laki-laki di Aceh dalam membantu pemerintah terhadap kesuksesan program syariat Islam di Aceh.

\section{Posisi Strategis Perempuan pada Dinas Syariat Islam dan Pengoptimalisasian Peran Perempuan Aceh}

Perempuan Aceh dalam konteks pelaksanaan syariat Islam di Aceh telah mengambil peran dalam multi bidang yaitu pemerintahan, politik, ekonomi, pendidikan dan tidak terkecuali termasuk telah mengambil berbagai posisi pada Dinas syariat Islam di provinsi Aceh termasuk pada Dinas Syariat Islam di tingkat Kabupaten/kota.

Umumnya perempuan Aceh yang bergabung dan bekerja pada Dinas syariat Islam merupakan Pegawai Negeri Sipil yang ditempatkan pada kantor Dinas Syariat Islam untuk memberikan layanan ${ }^{36}$ kepada masyarakat. Berdasarkan kebijakan pegawai negeri sipil, setiap pegawai yang telah memenuhi kriteria atau golongan tertentu, termasuk perempuan dibenarkan untuk mengisi jabatan tertentu pada Dinas Syariat Islam.

Berdasarkan berbagai informasi yang diperoleh, perempuan Aceh diberikan kesempatan mengisi jabatan strategis pada kantor Dinas Syariat Islam di Provinsi dan Kabupaten/Kota di Aceh. Hal ini sebagaimana jabatan Sekretaris/Bendahara Kantor Dinas Syariat Islam

${ }^{36}$ Muhammad Isa, et al., "Kewenangan dan Kedudukan Dinas Syariat Islam Dalam Tata Kelola Pemerintahan Aceh," dalam Diponegoro Journal of Social And Political of Science Tahun, 2016, h. 1-12. 
Kabupaten Aceh selatan dijabat oleh perempuan. Perempuan juga diberi kesempatan pengembangan karir dengan promosi jabatan pada kantor Dinas Syariat Islam di Aceh.

Pengoptimalisasian perempuan dalam pelaksanaan syariat Islam dapat dilakukan dengan memberikan dukungan pada perempuan dan pengembangan kompetensi perempuan dalam pemaham syariat Islam. Salah seorang Kepala Dinas Syariat Islam menjelaskan bahwa pengoptimalisasian peran perempuan dalam pelaksanaan syariat Islam di Aceh dilakukan dengan pengembangan kemampuan perempuan Aceh dalam pemahaman syariat Islam, sehingga mereka menjadi pembimbing terhadap masyarakat. ${ }^{37}$

Kepala Dinas Syariat Islam kabupaten selanjutnya menjelaskan bahwa pengoptimalisasian perempuan terhadap pelaksanaan syariat Islam di Aceh dapat dilakukan dengan cara memberikan kesempatan dan peluang kepada perempuan dalam pelaksanaan syariat Islam di Aceh, misalnya pelibatan perempuan sebagai dai/penceramah perempuan dan penyuluh agama serta kegiatan-kegiatan yang sosial dan syiar agama Islam di Aceh. ${ }^{38}$

Perlakuan secara demokratis diberikan kepada perempuan dalam sistem pemerintah, khususnya terhadap peran perempuan. Hasil observasi terhadap pengoptimalisasian peran perempuan pada Dinas syariat Islam di Kabupaten/kota bahwa sebagian pegawai pada Dinas syariat Islam Kabupaten/kota adalah perempuan dengan berbagai posisi jabatan pada struktural Dinas syariat Islam, seperti Kepala bagian, kepala subbagian, staf administrasi dan termasuk sebagai polisi syariat. ${ }^{39}$ Kesempatan tersebut dapat disebutkan sebagai bentuk poten $\mathrm{i}^{40}$ perempuan dan memiliki kemampuan bekerja secara baik terhadap posisi yang dipercayakan. Oleh karena itu, pemerintah agar dapat melakukan langkah-langkah strategis terhadap pelibatan perempuan dalam pelaksanaan syariat Islam di Aceh.

Pengoptimalisasian perempuan dalam pelaksanaan syariat Islam di Aceh, khususnya pada kantor Dinas syariat Islam Kabupaten/Kota dilakukan melalui beberapa pendekatan. Pertama, pengembangan kemampuan perempuan Aceh (SDM). Kedua, pelatihan pengembangan skil perempuan Aceh. Ketiga, pelibatan perempuan dalam struktur dan jabatan strategis pada Dinas syariat Islam, dan keempat, pelibatan perempuan sebagai petugas pengawas syariat Islam (WH).

Pengoptimalisasian peran perempuan dalam pelaksanaan syariat Islam di Aceh merupakan langkah positif dari pemerintah dalam rangka mendukung keefektifan pelaksanaan syariat Islam di Aceh dan menghindari ketidakpahaman dan kekeliruan yang dapat mengarah pada pelanggaran. ${ }^{41}$ Oleh karena itu, pengembangan kemampuan perempuan

\footnotetext{
${ }^{37}$ Wawancara dengan kepala Dinas Syariat Islam Aceh Utara, 3 Juni 2018.

${ }^{38}$ Wawancara dengan kepala Dinas Syariat Islam Pidie Jaya, 4 Agustus 2018.

${ }^{39}$ ObservaSi terhadap peran perempuan di Dinas Syariat Islam Aceh Selatan, 27 Juli 2018.

${ }^{40}$ M. Nasir Budiman, Pendidikan Dalam Perspektif Al Qur'an (Jakarta: Madani Press, 2001), h. 34.

${ }^{41}$ Agustin Hanafi, "Peran Perempuan Dalam Islam," dalam Gender Equality: Internasional Journal of Child and Gender Studies. Vol. 1, No. 1, Maret 2015, h. 15.
} 
terhadap pelaksanaan syariat Islam di Aceh agar dapat dilakukan pemerintah dalam rangka pengoptimalisasian peran perempuan, termasuk pengembangan kompetensi pegawai perempuan pada Dinas Syariat Islam di Aceh sehingga dapat memberikan layanan yang optimal kepada masyarakat.

Kiprah atau peran petugas perempuan pada Dinas Syariat Islam sangat penting, khususnya ketika ada hal-hal yang berkaitan dengan teknis di lapangan harus dilayani atau diselesaikan oleh perempuan. Oleh karena itu, pengembangan kompetensi pegawai perempuan pada Dinas Syariat Islam sangat penting untuk mendukung kesuksesan pelaksanaan SI di Aceh dan pengoptimalisasian keterlibatan perempuan dalam pelaksanaan SI di Aceh.

Selanjutnya, pelibatan perempuan dalam sistem pemerintahan dan sosial merupakan bagian dari pengoptimalisasian peran kaum perempuan dalam membantu sesama guna mencapai kehidupan yang damai dalam mengimplementasikan syariat Islam di bumi serambi Makkah. Aspek ini menunjukkan bahwa pemerintah Aceh memberikan perhatian yang sangat besar terhadap kiprah perempuan dalam membantu pembangunan di Aceh dalam konteks pelaksanaan syariat Islam.

\section{Persepsi Masyarakat terhadap Kedudukan Perempuan di Lingkungkan Dinas}

\section{Syariat Islam Provinsi Aceh}

Persepsi dalam hal ini terkait dengan pendapat atau pandangan masyarakat terhadap peran perempuan sebagai kepala Dinas Syariat Islam. Ludita Hardiyanti merujuk pada Bimo Walgito, persepsi adalah proses yang didahului oleh proses penginderaan, berupa proses diterimanya stimulus oleh individu melalui alat indera atau juga disebut proses sensoris. Tetapi proses tersebut tidak berhenti begitu saja, melainkan stimulus itu diteruskan dan proses selanjutnya merupakan proses persepsi. Proses persepsi sangat terikat dengan proses penginderaan, dan proses penginderaan merupakan proses utama dari proses persepsi. Melalui persepsi setiap individu akan menyadari tentang situasi dan keadaan di sekitarnya. Demikian juga keadaan diri individu. ${ }^{42}$

Obyek persepsi dapat berwujud situasi, benda-benda, dan juga berwujud manusia. Persepsi dalam perspektif psikologi sosial menjelaskan terkait proses mental yang berbeda yang digunakan untuk membentuk kesan dari orang lain. Hal ini bukan hanya bagaimana pada tingkat seseorang membentuk kesan, tetapi dalam membuat kesimpulan yang berbeda tentang orang lain didasarkan pada kebiaasn orang tersebut. ${ }^{43}$ Dahlia Lubis merujuk pada Rozalinda et al., persepsi seseorang dapat saja ditetapkan oleh faktor lingkungan, sistem

${ }^{42}$ Ludita Hardiyanti, "Persepsi Masyarakat Desa Terhadap Pencalonan Wakil Bupati Perempuan Dalam Perspektif Gender: Studi di Desa Logede, Kecamatan Pejagoan, Kabupaten Kebumen" (Skripsi, Fakultas Ilmu Sosial Universitas Negeri Yogyakarta, 2012), h. 4.

${ }^{43}$ Ibid. 
nilai, pendidikan, kepribadian, etnis, suku, dan latar belakang budaya. Multi faktor tersebut pada akhirnya dapat membentuk persepsi setiap individu baik pria maupun perempuan. ${ }^{44}$

Persepsi masyarakat dan karyawan perempuan terhadap peran perempuan pada posisi strategis di kantor Dinas Syariat Islam Kabupaten/kota provinsi Aceh berbeda-beda, ada yang setuju dan kurang setuju jika perempuan sebagai kepala Dinas Syariat Islam dengan alasan perempuan tidak pantas pada jabatan sebagai kepala Dinas Syariat Islam. Salah seorang karyawan menjelaskan bahwa jika kebijakan pemerintah membolehkan perempuan memimpin sebagai Kepala Dinas Syariat Islam. ${ }^{45}$ Penjelasan hampir sama juga dijelaskan oleh karyawan selanjutnya bahwa setuju saja karena perempuan juga memiliki kemampuan dalam memimpin seperti kaum laki-laki. ${ }^{46}$ Penjelasan hampir sama juga dijelaskan oleh karyawan selanjutnya bahwa perempuan juga memiliki keterampilan dalam memimpin, hanya saja selama ini tidak ada perempuan yang mengajukan atau ikut tes sebagai calon kepala Dinas Syariat Islam. ${ }^{47}$ Penjelasan senada juga di sampaikan oleh dua orang karyawan lain. Selanjutnya, penjelasan setuju terhadap perempuan menjabat sebagai kepala Dinas Syariat Islam di kabupaten/kota, juga diperoleh informasi dari masyarakat. Salah seorang masyarakat menjelaskan bahwa perempuan juga boleh menjabat posisi strategis pada Dinas Syariat Islam, namun harus memiliki kompetensi yang baik dan harus paham tentang syariat Islam. ${ }^{48}$

Persepsi informan terkait kedudukan perempuan sebagai kepala Dinas Syariat Islam bervariatif, ada yang setuju dan sebagian lainnya tidak setuju. Persepsi informan yang setuju terhadap kepemimpinan Dinas Syariat Islam dipimpin oleh perempuan mengajukan alasan. Pertama, Dinas Syariat Islam merupakan salah satu SKPA dan SKPK untuk kabupaten/ kota, dalam konteks ini setiap orang mempunyai hak yang sama untuk mencalonkan diri sebagai Kepala Dinas tersebut sehingga setiap masyarakat Aceh yang memenuhi syarat dapat mengikuti tes untuk posisi tersebut, termasuk perempuan. Kedua, perempuan memiliki kompetensi dalam kepemimpinan. Ketiga, peningkatan peran perempuan pada Dinas syariat Islam. Sedangkan informan yang tidak setuju dengan kepemimpinan perempuan pada Dinas syariat Islam di Kabupaten/Kota di Provinsi Aceh mengajukan alasan sebagai berikut. Pertama, Dinas syariat Islam tidak relevan dipimpin perempuan. Kedua, masih banyak tokoh dari kaum laki-laki yang lebih relevan sebagai pemimpin untuk Dinas syariat Islam. Ketiga, masih banyak tokoh dari kaum laki-laki yang berkompeten (memiliki kemampuan bidang itu). Keempat, masih banyak kaum laki-laki di Aceh lebih berkompeten dan memiliki kapasitas sebagai pemimpin. Persepsi masyarakat terkait informasi tersebut

${ }^{44}$ Dahlia Lubis, "Persepsi Pemuka Agama Terhadap Bias Gender Ditinjau Dari Latar Belakang Suku," dalam Journal of Contemporary Islam and Muslim Societies, Vol. 1, No. 1, 2017, h. 69.

${ }^{45}$ Wawancara dengan Pegawai Perempuan Dinas Syariat Islam Pidie Jaya, 4 Agustus 2018.

${ }^{46}$ Wawancara dengan Pegawai Perempuan di Dinas Syariat Islam Aceh Utara, 3 Juni 2018.

${ }^{47}$ Wawancara dengan Pegawai Perempuan Dinas Syariat Islam Aceh Selatan, 27 Juli 2018.

${ }^{48}$ Wawancara dengan masyarakat Aceh Utara, 5 Juli 2018. 
mengindikasikan perempuan tidak relevan sebagai Kepala Dinas Syariat Islam karena kedudukan Kepala Dinas Syariat Islam sangat urgen dalam pelaksanaan syariat Islam. Namun, umumnya masyarakat mengharapkan kepala pimpinan Dinas Syariat Islam agar mengelola pelaksanaan syariat Islam di Aceh terlaksana dengan efektif.

Persepsi masyarakat secara keseluruhan terhadap posisi strategi perempuan pada struktural kantor Dinas Syariat Islam memberikan penjelasan setuju dengan alasan perempuan perlu dilibatkan untuk mendukung pelaksanaan syariat Islam di Aceh dengan tepat dan efektif. Namun demikian, terdapat pula persepsi sebagian masyarakat tidak setuju jika Kepala Dinas syariat Islam dipimpin oleh perempuan dengan alasan tidak relevan dengan budaya Aceh. Hal ini pada dasarnya terletak pada aspek budaya atau adat. ${ }^{49}$ Namun demikian, pemerintah agar dapat menentukan kebijakan yang lebih bijak dalam rangka pelibatan perempuan secara efektif dalam pelaksanaan syariat Islam di Aceh.

\section{Kendala Pengoptimalisasian Peran Perempuan dalam Penerapan Syariat Islam di Aceh}

Kendala pengoptimalisasian peran perempuan dalam pelaksanaan syariat Islam di Aceh dalam penelitian ini dilihat melalui dua aspek: budaya dan kebijakan pemerintah Aceh. Kedua aspek tersebut lebih lanjut akan diuraikan pada hasil informasi penelitian berikut ini.

\section{Tradisi dan Budaya Aceh}

Pelibatan perempuan pada jabatan struktural kantor pemerintah ${ }^{50}$ pada dasarnya tidak ada kendala dan diatur dalam kebijakan atau aturan pegawai negeri sipil, sehingga semua jabatan di jajaran pemerintah mengacu pada peraturan yang berlaku. Setiap pegawai yang memenuhi persyaratan diberi kesempatan yang sama menjabat pada jabatan tertentu pada Dinas Syariat Islam di Aceh. Namun pelibatan dan pengoptimalisasian peran perempuan dalam struktur pemerintah dan publik dalam konteks adat dan istiadat Aceh dinilai tidak pantas, karena masih ada kaum laki-laki yang layak dan berkompetensi.

Salah seorang Kepala Dinas Syariat Islam menjelakan bahwa budaya Aceh pada dasarnya sangat harmonis dan tidak memberi dampak atau kendala terhadap pengoptimalisasian peran perempuan dalam pelaksanaan syariat Islam di Aceh, selama peran mereka sesuai

49 Zaki Ulya, "Dinamika Penerapan Hukum Jinayat Sebagai Wujud Rekonstruksi Syariat Islam di Aceh: Dynamic Appliction of Jinayat Law as Islamic Syariah Reconstruction in Aceh," dalam Jurnal Rechtsvinding, Vol. 5, No, 1, 2016, h. 142.

${ }^{50}$ Husni Jalil, "Kedudukan dan Fungsi Majelis Permusyawaratan Ulama Sebagai Mitra Kerja Pemerintah Aceh," dalam Jurnal Transformasi Administrasi, Vol. 2, No. 1, 2012, h. 311. 
dengan nilai-nilai budaya dan adat Aceh serta nilai-nilai syariat Islam yang berlaku di Aceh. ${ }^{51}$ Namun demikian, terdapat pula informasi terkait kendala pengoptimalisasian peran perempuan dalam pelaksanaan syariat Islam di Aceh, yaitu budaya dan adat Aceh. Perempuan tidak pantas banyak aktivitas di luar, apalagi di malam hari (dalam adat Aceh). Masih ada anggapan masyarakat bahwa perempuan tidak relevan menjadi pemimpin, khususnya sebagai kepala Dinas syariat Islam, dan perempuan tidak bisa tampil ke publik dan tidak bisa bekerja secara optimal, khususnya pada malam hari, menimbang perannya sebagai ibu terhadap anak-anak mereka sangat besar.

\section{Kebijakan Pemerintah Aceh}

Kebijakan pemerintah Aceh tentang pelaksanaan syariat Islam pada prinsipnya berlaku untuk umum. Syamsul Rijal, et al., menjelaskan bahwa pelaksanaan syariat Islam merupakan kewenangan pemerintah daerah. ${ }^{52}$ Oleh karena itu, segala bentuk kebijakan berupa peraturan, seperti qanun dan peraturan pemerintah daerah yang berhubungan dengan pelaksanaan SI merupakan kewenangan pemerintah Aceh.

Salah seorang kepala Dinas Syariat Islam menjelaskan bahwa perancangan peraturan pemerintah bersifat umum dan tidak boleh ada unsur diskriminasi terhadap masyarakat, termasuk qanun pelaksanaan syariat Islam berlaku untuk masyarakat Aceh secara umum dan tidak boleh ada unsur diskriminasi terhadap kelompok termasuk perempuan. ${ }^{53}$

Selanjutnya peneliti juga melakukan wawancara dengan para perempuan sebagai petugas pada kantor Dinas Syariat Islam Kabupaten/kota di Aceh. Salah seorang menjelaskan bahwa kebijakan pemerintah berupa qanun syariat Islam selama ini sudah bagus sekali. Isi qanun tidak melarang perempuan berkiprah dalam berbagai pekerjaan dan dibenarkan selama tidak melanggar dengan syariat Islam. ${ }^{54}$ Umumnya, mereka menjelaskan, tidak keberatan dengan pelaksanaan syariat Islam di Aceh karena perempuan dapat ikut serta dalam pelaksanaannya. ${ }^{55}$

Informasi tersebut sejalan dengan hasil observasi di lapangan bahwa sejauh ini tidak ditemukan qanun yang terkait dengan pelaksanaan syariat Islam yang menghambat terhadap pengoptimalisasian peran perempuan dalam pelaksanaan syariat Islam di Aceh. ${ }^{56}$ Sejauh informasi yang diperoleh bahwa kebijakan pemerintah Aceh seperti qanun sudah baik sekali. Qanun syariat Islam Aceh mengandung nilai-nilai demokratis, sehingga pada pelaksanaan dapat diterima oleh masyarakat dan berlaku untuk umum.

${ }^{51}$ Wawancara dengan Kepala Dinas Syariat Islam Pidie Jaya, 4 Agustus 2018.

${ }^{52}$ Syamsul Rijal, et al., Dinamika Sosial Keagamaan Dalam Pelaksanaan Syariat Islam (Banda Aceh: Dinas Syariat Islam, 2017), h. 40.

${ }^{53}$ Wawancara dengan Kepala Dinas Syariat Islam Aceh Selatan, 27 Juli 2018.

${ }^{54}$ Wawancara dengan Masyarakat Aceh Selatan, 27 Juli 2018.

${ }^{55}$ Wawancara dengan Masyarakat Syariat Islam Aceh Utara, 27 Juli 2018.

${ }^{56}$ Observasi Pelaksanaan Syariat Islam di Pidie Jaya, 4 Agustus 2018. 
Pelaksanaan syariat Islam di Aceh berlaku umum terhadap semua masyarakat Aceh, laki-laki dan perempuan. Perancangan kebijakan berupa qanun dilakukan secara demokratis dengan pertimbangan berbagai aspek, termasuk pertimbangan sosiologis masyarakat Aceh. Dengan demikian, kebijakan pelaksanaan syariat Islam di Aceh sangat humanis atas dasar pertimbangan unsur-unsur kemanusiaan dan kemaslahatan masyarakat Aceh secara umum. Pelaksanaan syariat Islam tidak melanggar hak masyarakat Aceh, karena syariat Islam merupakan ajaran agama yang dianut masyarakat Aceh pada umumnya.

Pelaksanaan Qanun syariat Islam tidak membatasi terhadap ruang gerak perempuan di Aceh, ${ }^{57}$ khusus perempuan untuk mengembangkan karirnya dalam berbagai sektor terutama ekonomi, politik, dan pemerintahan. Dengan demikian, kebijakan pemerintah Aceh berupa qanun syariat Islam di Provinsi Aceh tidak menghambat terhadap pengoptimalisasian peran perempuan, khususnya peran perempuan dalam mendukung terhadap pelaksanaan syariat Islam secara kâffah di Aceh.

Qanun pelaksanaan syariat Islam berlaku secara universal untuk semua masyarakat Muslim di Aceh dan memberikan peran yang sama baik untuk perempuan maupun lakilaki, tidak ada pembatasan ruang gerak perempuan, mereka berkecimpung dalam bidang politik, ekonomi, pendidikan, sosial, dan seni. Hal ini mengindikasikan bahwa syariat Islam tidak mendiskreditkan para perempuan di Aceh.

\section{Penutup}

Implementasi syariat Islam di Propinsi Aceh merujuk pada kebijakan politik pemerintah pusat berupa UU Nomor 44 Tahun 1999 tentang Keistimewaan Provinsi Aceh dan UU Nomor 18 Tahun 2001 tentang Otonomi Khusus untuk provinsi Nanggroe Aceh Darussalam. Berdasar kebijakan tersebut, propinsi Aceh memiliki kewenangan pelaksanaan syariat Islam secara menyeluruh. Pelaksanaan syariat Islam di propinsi Aceh melibatkan semua komponen masyarakat, termasuk kaum perempuan. Perempuan Aceh telah ikut berperan mendukung pemerintah terhadap kesuksesan pelaksanaan syariat Islam. Perempuan bagian mitra pemerintah dalam pelaksanaan syariat Islam. Pengoptimalisasian perempuan dalam pelaksanaan syariat Islam di Propinsi Aceh dilakukan melalui pelibatan perempuan dalam berbagai sektor pemerintahan di Aceh, termasuk pelibatan perempuan dalam struktur Dinas Syariat Islam Propinsi dan Dinas Syariat Islam Kabupaten/kota.

Keterlibatan peran perempuan dalam pelaksanaan syariat Islam di Aceh juga dapat dilihat pada peran perempuan dalam posisi strategis pada Dinas Syariat Islam di Kabupaten/ kota di Aceh. Perempuan diberi posisi dan kewenangan strategis, seperti sekretaris kantor,

${ }^{57}$ Ridwan Nurdin, "Kedudukan Qanun Jinayat Aceh dalam Sistem Hukum Pidana Nasional Indonesia," dalam MIQOT: Jurnal Ilmu-ilmu Keislaman, Vol. 42, No. 2, 2018, h. 356-378. 
bendahara, dan kepala bagian, serta pelibatan perempuan sebagai polisi syariat (wilayatul hisbah). Namun demikian, pengoptimalisasian peran perempuan dalam pelaksanaan syariat Islam di Aceh masih terdapat kendala dari aspek budaya dan adat Aceh yang masih memberi kesan perempuan tidak layak untuk jabatan kepala Dinas Syariat Islam, sehingga dari awal pemberlakuan syariat Islam di Aceh sampai dengan saat ini, lembaga tersebut belum pernah dipimpin oleh perempuan, baik sebagai Kepala Dinas Syariat Islam Propinsi Aceh ataupun Kepala Dinas Syariat Islam Kabupaten/Kota. Namun demikian, secara keseluruhan perempuan terlibat secara aktif dalam pelaksanaan syariat Islam di Aceh.

\section{Pustaka Acuan}

Abubakar, Al Yasa. Bunga Rampai Pelaksanaan Syariat Islam (Pendukung Qanun Pelaksanaan Syariat Islam). Banda Aceh: Dinas Syariat Islam, 2009.

Alamul, Huda. "Peran Perempuan dalam Pemberdayaan Ekonomi Syariah," dalam De Jure: Jurnal Hukum dan Syariah, Vol. 5. No. 1, 2013.

Arikunto, Suharsimi. Manajemen Penelitian. Jakarta: Rineka Cipta, 2003.

Budiman, M. Nasir. Pendidikan Dalam Perspektif al-Qur'an. Jakarta: Madani Press, 2001.

Fajriah, Nurul, et al. Dinamika Peran Perempuan Aceh Dalam Lintasan Sejarah. Banda Aceh: Yayasan PeNa, 2007.

Halimah, Siti dan Humaidah Hasibuan. "Respons Tokoh Ormas Islam Terhadap Peran Publik Perempuan," dalam MIQOT: Jurnal Ilmu-ilmu Keislaman, Vol. 42, No. 2, 2018.

Hanafi, Agustin. "Peran Perempuan Dalam Islam," dalam Gender Equality: Internasional Journal of Child and Gender Studies, Vol. 1, No. 1, Maret 2015.

Hardiyanti, Ludita. "Persepsi Masyarakat Desa Terhadap Pencalonan Wakil Bupati Perempuan Dalam Perspektif Gender: Studi di Desa Logede, Kecamatan Pejagoan, Kabupaten Kebumen.” Fakultas Ilmu Sosial Universitas Negeri Yogyakarta, 2012.

Hidayati, Rahma, et al. "Gender dan Gaya Kepemimpinan Perempuan di Jabatan Publik: Studi Fenomenologi Pelaksanaan Syariat Islam di Aceh," dalam Jurnal Community, Vol. 4. No, 2, 2019.

Isa, Muhammad, et al. "Kewenangan dan Kedudukan Dinas Syariat Islam Dalam Tata Kelola Pemerintahan Aceh," dalam Diponegoro Journal of Social And Political of Science Tahun, Vol. 5, No. 02, 2016.

Jalil, Husni. "Kedudukan dan Fungsi Majelis Permusyawaratan Ulama Sebagai Mitra Kerja Pemerintah Aceh," dalam Jurnal Transformasi Administrasi. Vol. 2, No. 1, 2012.

Keumala, Syahnaz Oriza, et al. "Keterwakilan Anggota Legislatif Perempuan Dalam Perumusan Qanun Jinayat Provinsi Aceh: Suatu Kajian Terhadap Peran Anggota Legislatif Perempuan di Dewan Perwakilan Rakyat Aceh," dalam Jurnal Ilmiah Mahasiswa Fakultas Ilmu Sosial \& Ilmu Politik, Vol. 2, No. 2, 2017. 
Lubis, Dahlia. "Persepsi Pemuka Agama Terhadap Bias Gender Ditinjau Dari Latar Belakang Suku," dalam Journal of Contemporary Islam and Muslim Societies, Vol. 1, No. 1, 2017.

Mahfud, et al. "Dekonstruksi Peran Tuha Peut Perempuan dalam Menjaga Perdamaian di Aceh," dalam Kanun: Jurnal Ilmu Hukum, Vol. 19, No. 3, 2017.

Mahmuddin. "Tuha Peut Perempuan: Peluang dan Diferensiasi Sosial Pembangunan Gampong di Aceh," dalam Jurnal Peurawi, Vol. 2. No, 1, 2019.

Muhadjir, Noeng. Metodologi Penelitian Kualitatif. Yogyakarta: Bayu Indra Grafika, 1996.

Muhammad, Rusjdi Ali. Revitalisasi Syari'at Islam di Aceh: Problem, Solusi, dan Implementasi. Kerjasama IAIN Ar-Raniry, Nanggroe Aceh Darussalam dengan Penerbit Logos Wacana Ilmu, 2003.

Munawiah. "Kedudukan Perempuan Dalam Budaya Aceh," dalam Jurnal Ar-Raniry Media Kajian Keislaman, Vol. 1. No. 87, 2011.

Nasir, Muhammad. "Syariat Islam dan Ngangkang Style: Mengenal Kearifan Lokal dan Identitas Perempuan Aceh," dalam MIQOT: Jurnal Ilmu-Ilmu Keislaman, Vol. 37, No. 1, 2013.

Nurdin, Abidin, et al. Syariat Islam dan Isu-Isu Kontemporer. Banda Aceh: Dinas Syariat Islam, 2011.

Nurdin, Ridwan. "Kedudukan Qanun Jinayat Aceh dalam Sistem Hukum Pidana Nasional Indonesia," dalam MIQOT: Jurnal Ilmu-ilmu Keislaman, Vol. 42, No. 2, 2018.

Putry, Raihan. "Kepemimpinan Perempuan dalam Perspektif Islam," dalam Jurnal Mudarrisuna: Media Kajian Pendidikan Agama Islam, Vol. 5, No. 2, 2015.

Rijal, Syamsul, et al. Dinamika Sosial Keagamaan Dalam Pelaksanaan Syariat Islam. Banda Aceh: Dinas Syariat Islam, 2017.

Saiful, T. "Gender Perspektif dalam Formalisasi Syariat Islam di Aceh," dalam Kanun: Jurnal Ilmu Hukum, Vol. 18, No. 2, 2016.

Saparudin. "Gerakan Keagamaan dan Peta Afiliasi Ideologis Pendidikan Islam di Lombok," dalam MIQOT: Jurnal Ilmu-ilmu Keislaman, Vol. 42, No, 1, 2018.

Siregar, Muhammad Habibi. "Islam, Patron Sosial, Pseudo Identitas Masyarakat Perkotaan di Kota Medan," dalam MIQOT: Jurnal Ilmu-ilmu Keislaman, Vol. 41. No.2, 2018.

Sugiyono. Metode Penelitian Pendidikan Pendekatan Kuantitatif, Kualitatif, dan R \& D. Bandung: Alfabeta, 2011.

Sulaiman. Studi Syariat Islam di Aceh. Banda Aceh: Madani Publisher, 2018.

Syahnan, Mhd. Hukum Islam dalam Bingkai Transdisipliner. Medan: Perdana Publishing, 2018.

Syahnan, Mhd., Mahyuddin, dan Abd. Mukhsin. "Reconsidering Gender Roles in Modern Islam: A Comparison of the Images of Muslim Women Found in the Works of Sayyid Qutb and "Â'ishah 'Abd Rahmân," dalam International Journal of Humanities and Social Science Invention Vol. 6 (10) 2017. 
Syamsuri dan Okta Yuripta Syafitri. "Maqâshid Syarî'ah Approach on the Empowerment of Human Resources in Mulyodadi Village Bantul Yogyakarta," dalam MIQOT: Jurnal Ilmu-ilmu Keislaman, Vol. 42. No. 2, 2018.

"Tokoh Perempuan dan Da'iyah Aceh Menjadi Garda Terdepan Dalam Pelaksanaan Syariat Islam di Aceh," dalam https://dsi.acehprov.go.id, 30 Agustus 2017.

Ulya, Zaki. "Dinamika Penerapan Hukum Jinayat Sebagai Wujud Rekonstruksi Syariat Islam di Aceh: Dynamic Appliction of Jinayat Law as Islamic Syariah Reconruktion in Aceh," dalam Jurnal Rechtsvinding. Vol. 5, No, 1, 2016.

Undang-Undang Nomor 18 Tahun 2001 tentang Otonomi Khusus untuk Provinsi Nanggroe Aceh Darussalam.

Undang-Undang Nomor 44 Tahun 1999 tentang Keistimewaan Provinsi Aceh.

Undang-Undang Republik Indonesia Nomor 11 Tahun 2006 Tentang Pemerintahan Aceh. 